\title{
Public Open Space Design Study on the Basis of Microclimate and Spatial Behavior in Hot and Cold Weather Conditions in Downtown
}

\author{
Area \\ Zhiming GUO ${ }^{1}$, Tsuyoshi SETOGUCHI ${ }^{1}$, Norihiro WATANABE ${ }^{1} \& \mathrm{Ke} \mathrm{HUO}^{2}$ \\ ${ }^{1}$ Faculty of Engineering, Graduate School of Engineering, Hokkaido University, Sapporo, Japan \\ ${ }^{2}$ JangHo Architecture College, Northeastern University, Shenyang, China \\ Correspondence: Zhiming GUO, Faculty of Engineering, Graduate School of Engineering, Hokkaido University, \\ Sapporo, Hokkaido, Japan. Tel: 81-080-5722-6688. E-mail: burningrain1988@eis.hokudai.ac.jp
}

Received: January 10, 2018 Accepted: January 18, $2018 \quad$ Online Published: January 30, 2018

doi:10.5539/mas.v12n2p128 URL: https://doi.org/10.5539/mas.v12n2p128

The research is financed by JSPS KAKENHI Grant Number JP25249082. The first author is supported by the Chinese Scholarship Council (CSC) scholarship (File No. 201406080003).

\begin{abstract}
Microclimate in open space affected by the urban layouts and spatial forms plays an important role in the outdoor comfort, thus the outdoor activities based on the comfort sensation will directly affected by the microclimate. An outstanding open space should satisfy different requirements of outdoor activities and create relatively comfortable sensation.

Most studies have been conducted on these relationships only above 0 Celsius degree. However, only few have focused on extreme situations in both hot and cold seasons. Therefore, from microclimate perspective, taking people's comfort and spatial behaviors as criterions, this research discussed how the open space forms affect microclimate, thus affect comfort sensation and spatial behaviors. The outcomes may provide some useful insights for planners and architects to understand the relationship among microclimate, open space and people.

Results showed that microclimate obviously affected people's comfort. In hot season, shade and air-flow played crucial roles in outdoor comfort. People tend to stay outside in the shade and the area with higher air velocity. After sunset is popular period for outdoor activities. In cold season, at the same ambient temperature, lower air velocity raised the comfort level. Shade also had influences on comfort sensation but do not affect spatial behaviors significantly.

This paper also proposes optimization design proposals of densely populated open space based on extreme microclimate and spatial behaviour.
\end{abstract}

Keywords: outdoor comfort, urban design, street canyon, activities, optimization design

\section{Introduction}

Open space that accommodate daily social activities plays an important role in cities. One of open space design targets is attracting more people to enjoy the outdoor environment (Carr, 1993; Marcus, 1997; Gehl, 2011; Maruani, 2007). Most open spaces are based on a type of open space formed by streets and buildings. One of the main types of open space is urban canyon that defined as the space composed of the street and its flanking buildings (Nunez, 1977). The city commercial zones are mostly planned in downtown urban canyons which are densely populated, and convenient for traffic. These properties lead to crucial status of urban canyon. For field surveys of urban canyon space, researching the commercial open space has obvious typicality and research value than any other types of urban space (Spagnolo, 2003).

On the basis of spatial types in the urban canyon, the microclimate undergoes complex changes, thus affecting outdoor activities dramatically. Many studies have researched outdoor thermal comfort and outdoor activities influenced by microclimate (Nikolopoulou, 2007; Shimazaki, 2011; Thorsson, 2007; Eliasson, 2007). An increasing number of researchers have focused on the relationship between the microclimate and urban forms. 
Several studies have proved that shade and exposure to sunlight greatly influence ambient temperature in urban canyon, thus affecting users' feelings of comfort (Bourbia, 2010; Hwang, 2011; Andreou, 2012; Andreou, 2013, 2014; Shahrestani, 2015). Erell et al. (2012) have provided new perspective on interaction between microclimate and urban landscape for architects and urban designers. Among them, however, few studies have researched regions that suffer wide differences in temperature between summer and winter.

The relationship between microclimate and people's reactions, including comfort sensation and spatial behaviors in urban canyon should be paid more attention, especially in extreme weather. Li (1994) researched on small urban spaces in New York in winter to study the spatial behaviour influenced by climatic conditions. By using microclimate monitoring and interviews, Lai (2014) conducted a field survey at a park in northern China revealed the relationship between human comfort and each parameter of boreal climate. Furthermore, this research estimated northerners' comfort level and cold-resistant level by multimethod. Baruch (1998) discussed the relationship among building, design, and climate, introducing design principles in different climate regions, broadly including cold regions. Using wind and snow tunnel simulation and evaluation, Setoguchi et al. (2004, 2007, 2008, 2009) and Watanabe et al. (2016) discussed design procedures for winter cities, especially those suffering heavy snow. They discussed urban structures and building forms which are suitable for outdoor activities in cold season. Meng (2010) provided open space design guidelines for downtown areas suffering strong winds and low winter temperatures by simulating various types of downtown, high-rise buildings in a wind tunnel.

An outstanding open space should satisfy different requirements of outdoor comfort in different climate conditions. Other than the indoor space which can be created to satisfy the needs of the occupants, the outdoor space which affected by urban microclimate should be built by understanding the microclimate and should responds to them in appropriate ways (Erell et al.,2012). By researching the extreme urban microclimate situation, this study may provide useful insights for planner, architects and environment engineers to demonstrate the microclimate factors affected outdoor comfort significantly. Through microclimate measurement with public feedback in a central open space in northern China, this research discusses important elements that significantly affect people's sensations and behaviors, especially, how to optimize the open space design to prevent poor situations in hot summer and cold winter.

\section{Method}

\subsection{Study Area}

The study case is a canyon type open space located in the central area of Shenyang in northern China $\left(41^{\circ} 48^{\prime} 01.11^{\prime \prime} \mathrm{N}, 123^{\circ} 27^{\prime} 49.33^{\prime \prime} \mathrm{E}\right)$, which has long, severely cold winter and relatively short summer (Chinese State Bureau of Technology Supervision (CSBTS), 1994). The annual temperature range which undergoes over approximately $60^{\circ} \mathrm{C}$ (China Meteorological Administration, 2014) is relatively larger than that of other areas; however, several weeks in summer also suffer high temperatures.

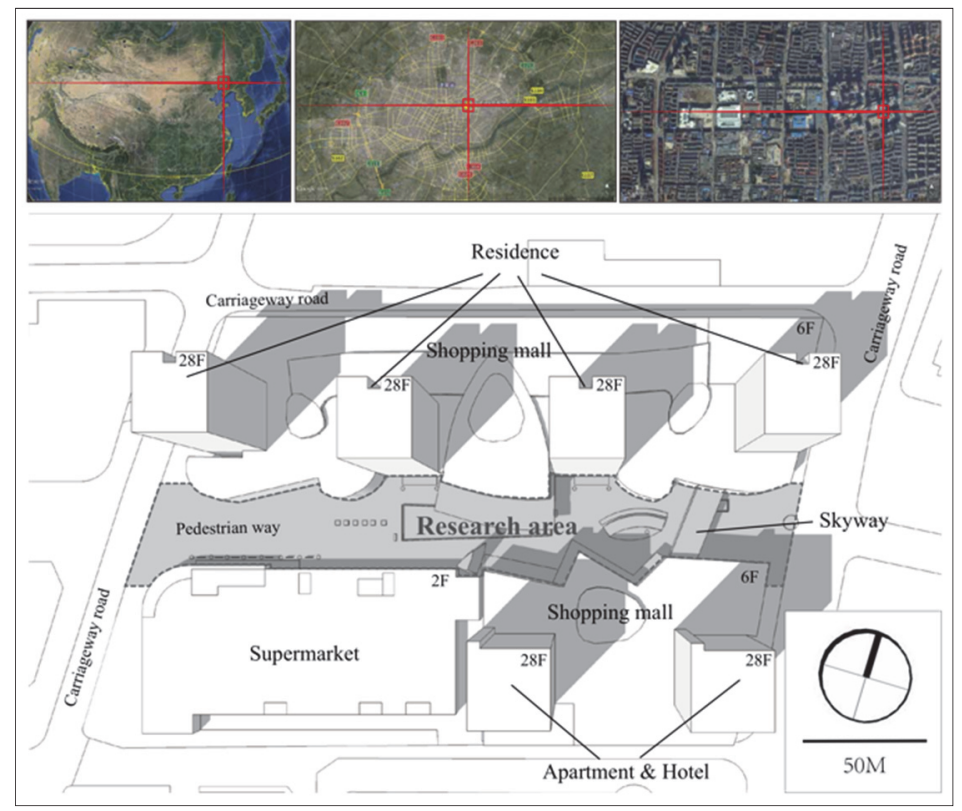

Figure 1. Research area in Shenyang, northern China 
The study area is located at the mid-street in Shenhe district, Shenyang with approximately 400-600 thousands of tourists per day (ZHANG, 2008), named as one of the most popular public spaces in the downtown area. There are resourceful public facilities with building area of about $282,700 \mathrm{~m}^{2}$ like shopping malls, supermarkets, residences, hotels, and apartments. The subway station is located at the second underground floor of a shopping mall. As Fig. 1 shows, this place is a pedestrian street canyon (approximately $35 \times 280 \mathrm{~m}^{2}$ ). The area is mostly covered with hard materials with several tree pools. There are more than 20 entrances of the buildings opening to the pedestrian street. As an integrated public area, many and various subjects can be found to participate as references in the research.

\subsection{Field Survey}

The hottest period in summer and coldest period in winter were chosen to research the extreme climate situation on the basis of 5 years (2009-2014) daily maximum and minimum temperatures from July to September in summer and December to February in winter (Fig. 2). Jul. 28-Aug.9, 2015 (12 days in summer) and Jan. 15-29 (15days in winter), 2016 were chosen as the survey periods.

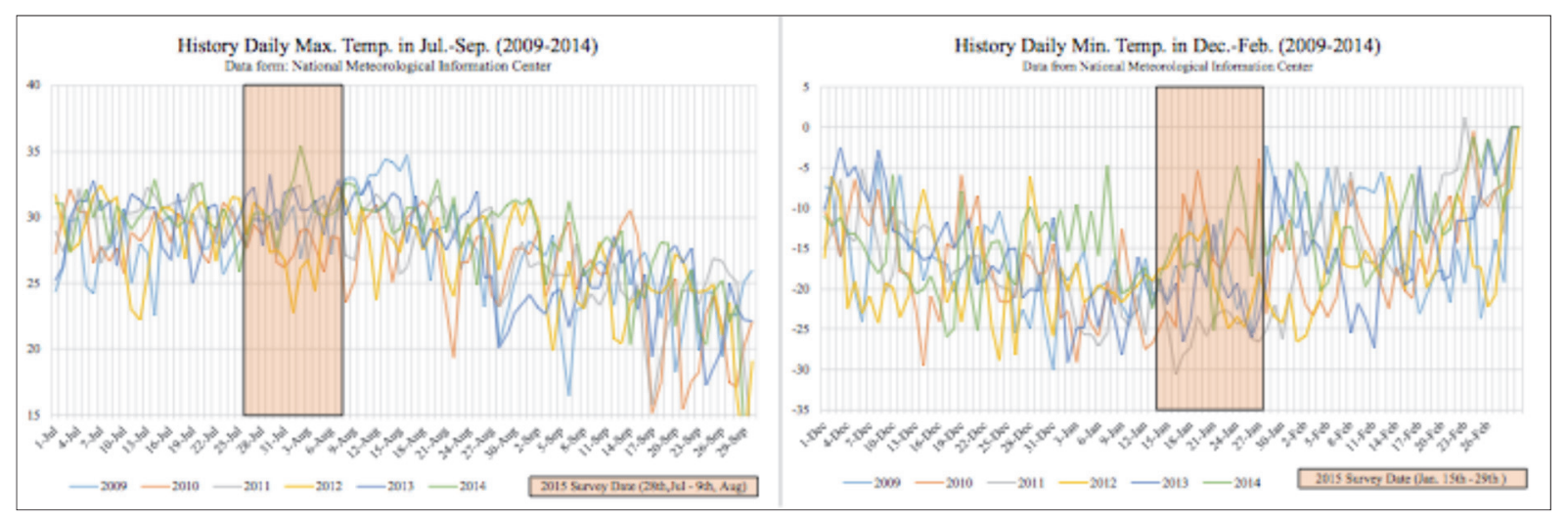

Figure 2. Historical daily maximum and minimum temperatures from July to September and December to February 2009-2014 (China Meteorological Administration, 2014)

In the research area, 4 areas named west center line, east center line, north edge side and south edge side, including 15 measurement points were separated depending on space characteristics (see Fig. 3). As shown in Table 1, the microclimate parameters were recorded at each point every 15 minutes from 9:30 to 20:00, including ambient temperature $\left(T_{a}\right)$, air velocity $(V)$, relative humidity $(R H)$, globe temperature $\left(T_{g}\right)$ and shade situation. The wind chill (WC) will be recorded during the winter survey day.

Mean radiant temperature $\left(T_{\mathrm{mrt}}\right)$ is defined as the "uniform temperature of an imaginary enclosure in which the radiant heat transfer from the human body equals the radiant heat transfer in actual non-uniform enclosure" (ASHRAE, 2001). It is based on the conversion of radiative energy between the absorbing and the emitting of two objects. In this study, the $T_{\text {mrt }}$ is estimated using the globe temperature method. Depending on the previous study, there are relatively small differences between the globe temperature methods and other complicated methods (Thorsson, 2007). Tmrt is calculated based on the following formula (ASHRAE, 2001):

$$
\mathrm{T}_{\mathrm{mrt}}=\left[\left(\mathrm{T}_{\mathrm{g}}+273\right)^{4}+\frac{1.10 \times 10^{8} \mathrm{~V}^{0.6}}{\varepsilon \mathrm{D}^{0.4}}\left(\mathrm{~T}_{\mathrm{g}}-\mathrm{T}_{\mathrm{a}}\right)\right]^{\frac{1}{4}}-273
$$

where $\mathrm{T}_{\mathrm{mrt}}$ is mean radiant temperature $\left({ }^{\circ} \mathrm{C}\right), \mathrm{T}_{\mathrm{g}}$ is globe temperature $\left({ }^{\circ} \mathrm{C}\right), \mathrm{T}_{\mathrm{a}}$ is air temperature, $\mathrm{V}$ is air velocity $(\mathrm{m} / \mathrm{s}), \mathrm{D}$ is globe diameter $(\mathrm{m})$ (in this study $\mathrm{D}=0.075 \mathrm{~m}), \varepsilon$ is emissivity $(0.95$ for black-colored globe).

The Physiological Equivalent Temperature (PET) (Mayer, 1987) was employed in this research as a reference of the objective thermal comfort level. It can be defined as a temperature dimension index in degrees Celsius $\left({ }^{\circ} \mathrm{C}\right)$ based on the Munich Energy-balance model for Individuals (MEMI) (Höppe, 1999). The PET can be calculated by using the software (e.g., RayMan) (Matzarakis, 2007) with inputting parameters of positional information, basic human factors, $\mathrm{T}_{\mathrm{a}}, \mathrm{V}, \mathrm{RH}$ and $\mathrm{T}_{\mathrm{mrt}}$. It is also used by the human bio-meteorological evaluation of climate in urban and regional planning in German (VDI 3787) (VDI, 1998).

The environmental comfort sensation votes (CSV) which can be defined as subjectively integrated reactions of local people to the environment were also collected at the same time with recording the microclimate data (see Table 2) (Tanabe, 1988). 
Panoramic images and the time-lapse videos were taken during the survey for analyzing the people presents and their position relations (Fig. 3). As a comparison research of people present in and out of shade in summer and winter, two clear days, Aug.4, 2015 (summer) and Jan. 22, 2016 (winter) were chosen to analyze the spatial positions by counting and drawing down the people's position according to the panoramas and videos every 30 minutes. Besides the real shade situation recording, this study also simulated the shade in Aug. 4th and Jan. 22nd as references of the behaviour analyses depending on the solar incident angle (China Meteorological Bureau, 2005; MOHURD, 1994).

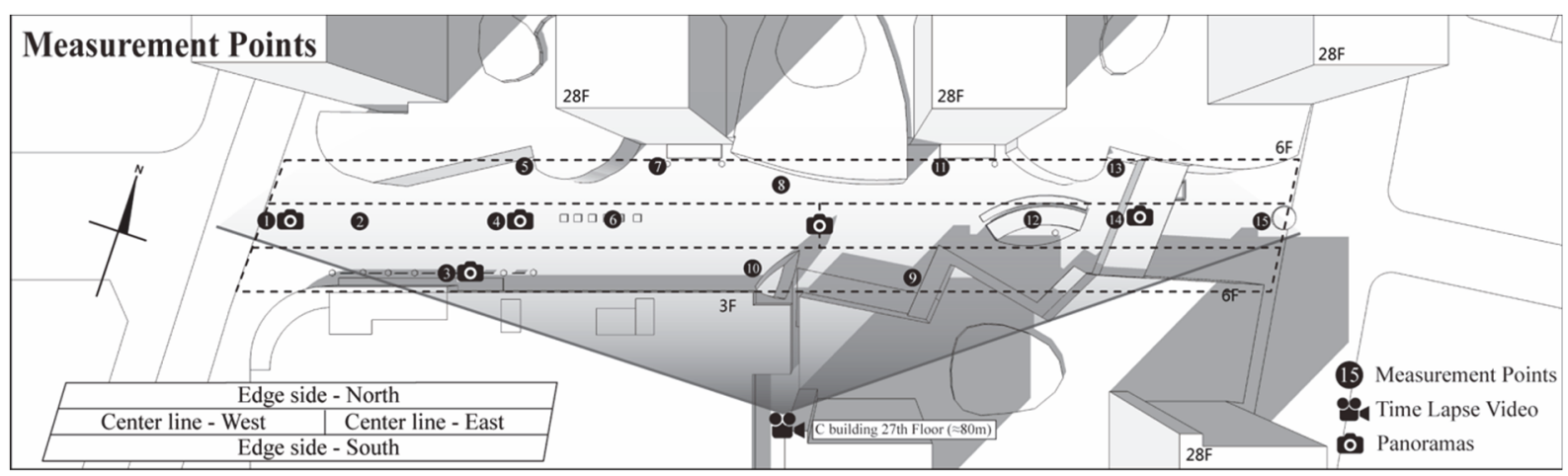

Figure 3. Space types, position information, and measurement methods of central open space, Shenyang, Northern China

Table 1. Sensor specifications and measurement height

\begin{tabular}{cccccc}
\hline Sensor & Parameter & Accuracy & Resolution & Range & Setting place \\
\hline & $\mathrm{V}$ & $3 \%$ & $0.1 \mathrm{~m} / \mathrm{s}$ & 0.6 to $40.0 \mathrm{~m} / \mathrm{s}$ & \\
Kestrel & $\mathrm{T}_{\mathrm{a}}$ & $0.5^{\circ} \mathrm{C}$ & $0.1{ }^{\circ} \mathrm{C}$ & -29.0 to $70.0{ }^{\circ} \mathrm{C}$ & From point No. 1 to No. 15, \\
4500 & $\mathrm{RH}$ & $3.0 \%$ & $0.1 \%$ & 5 to $95 \%$ non-condensing & $1.5 \mathrm{~m}$ as the average height of \\
& $\mathrm{WC}$ & $0.9^{\circ} \mathrm{C}$ & $0.1{ }^{\circ} \mathrm{C}$ & $\begin{array}{c}\text { Refer to Ranges for the V } \\
\text { and } \mathrm{T}_{\mathrm{a}} \text { Sensors }\end{array}$ & the head. \\
(winter) & $0.3^{\circ} \mathrm{C}$ & $0.1{ }^{\circ} \mathrm{C}$ & -40 to $110^{\circ} \mathrm{C}$ & \\
\hline
\end{tabular}

Note. Wind chill temperature (WC) results from combining the effect of air velocity and ambient temperature. Calculated based on the NWS Wind Chill Temperature Index (The National Weather Service (NWS), 2011).

Table 2. The scale used by participants for subjective responses about comfort sensation during field surveys

\begin{tabular}{cc}
\hline Value & Comfort sensation vote \\
\hline-3 & Very uncomfortable \\
-2 & Uncomfortable and unacceptable \\
-1 & Uncomfortable, but acceptable \\
0 & Neutral \\
1 & Slightly comfortable \\
2 & Comfortable \\
3 & Very comfortable \\
\hline
\end{tabular}

\section{Results}

\subsection{Sensation Analysis with Microclimate Parameters}

During the survey, 2489 groups of microclimate data and the corresponding CSV in summer and 2501 groups in winter were collected. The measured $\mathrm{T}_{\mathrm{a}}$ range were $24.4-35.9^{\circ} \mathrm{C}$ in summer, $-21.6-2.2^{\circ} \mathrm{C}$ in winter. The maximum temperature range between summer and winter was $57.5^{\circ} \mathrm{C}$. The measured air velocity range were 0 $7.1 \mathrm{~m} / \mathrm{s}$ in summer and $0-4.8 \mathrm{~m} / \mathrm{s}$ in winter. The mean air velocity in summer was $1.2 \mathrm{~m} / \mathrm{s}$ higher than in winter $(1 \mathrm{~m} / \mathrm{s}$ ). The RH range were $36-100 \%$ in summer (mean RH was $38.8 \%$ ) and $20-56.2 \%$ in winter (mean RH was $20 \%)$.

Table 3 displays the correlations (Blalock, 1972) between CSV and microclimate data by using the software IBM SPSS Statistics (Version 20.0.0) $\left(\mathrm{N}_{\text {summer }}=2489, \mathrm{~N}_{\text {winter }}=2501\right)$. It can be used to evaluate the microclimate elements which will affect the comfort level greater. The higher the correlation coefficient, the greater influence 
on comfortable level. A measure of linear correlation between the two variables $\mathrm{X}$ and $\mathrm{Y}$, a value is given between +1 and -1 , inclusively, with 1 indicating total positive correlation, 0 indicating no correlation, and -1 indicating total negative correlation.

The results indicated that in summer (Table 3a), all measured factors affected CSV significantly. Among them, shade had the highest correlation $(r=-0.464)$ with CSV, followed by $R H(r=0.449) . T_{a}$ was third, with a coefficient of -0.421 , follow by the $\mathrm{T}_{\mathrm{mrt}}(\mathrm{r}=-0.234)$. The weakest correlation with CSV was air velocity, with a coefficient of 0.222 . More shade, lower $\mathrm{T}_{\mathrm{a}}$, higher air velocity, and higher RH improved sensations of comfort.

In winter (Table $3 b$ ), wind chill is employed as an important part for comfort evaluation. There are significant correlations between CSV and all measured factors. $T_{\text {mrt }}$ affected CSV most with a coefficient of 0.336, followed by wind chill $(\mathrm{r}=0.310)$. Correlation coefficients decreased gradually from $\mathrm{T}_{\mathrm{a}}(\mathrm{r}=0.298)$ and shade $(\mathrm{r}=0.236)$ to air velocity $(-0.074)$. Higher wind chill, less shade, higher $\mathrm{T}_{\mathrm{a}}$, and lower air velocity improve comfort sensations.

Consequently, all the parameters mentioned in this part will affect the CSV. However, there is no correlation coefficients above 0.5 , that is, no single parameter will affect the CSV as a leading role. All the factors have come together on the comfort level.

Table 3a. Correlations between comfort sensation votes (CSV) and microclimates in summer

\begin{tabular}{|c|c|c|c|c|c|c|c|}
\hline \multirow{7}{*}{ 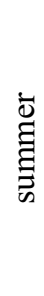 } & & $\mathrm{CSV}$ & Shade & $\mathrm{T}_{\mathrm{a}}$ & Tmrt & V & $\mathrm{RH}$ \\
\hline & $\mathrm{CSV}$ & 1 & & & & & \\
\hline & Shade & $-.464 * *$ & 1 & & & & \\
\hline & $\mathrm{T}_{\mathrm{a}}$ & $-.421 * *$ & $.288 * *$ & 1 & & & \\
\hline & $\mathrm{T}_{\mathrm{mrt}}$ & $-.234 * *$ & $.250 * *$ & $.215^{* *}$ & 1 & & \\
\hline & $\mathrm{V}$ & $.222 * *$ & $-.080 * *$ & $-.157 * *$ & $.216^{* *}$ & 1 & \\
\hline & RH & $.449 * *$ & $-.287 * *$ & $-.685^{* *}$ & $-.283 * *$ & $.165^{* *}$ & 1 \\
\hline
\end{tabular}

** Correlation is significant at the 0.01 level (2-tailed).

Table 3b. Correlations between comfort sensation votes (CSV) and microclimates in winter

\begin{tabular}{|c|c|c|c|c|c|c|c|}
\hline \multirow{7}{*}{. } & & CSV & Shade & $\mathrm{Ta}$ & Tmrt & V & WC \\
\hline & $\mathrm{CSV}$ & 1 & & & & & \\
\hline & Shade & $.236^{* *}$ & 1 & & & & \\
\hline & $\mathrm{T}_{\mathrm{a}}$ & $.298 * *$ & $.036 * *$ & 1 & & & \\
\hline & $\mathrm{T}_{\mathrm{mrt}}$ & $.336^{* *}$ & $.157 * *$ & $.461 * *$ & 1 & & \\
\hline & $\mathrm{V}$ & $-.074 * *$ & -0.008 & $.124 * *$ & $.260 * *$ & 1 & \\
\hline & WC & $.310 * *$ & $.038 *$ & $.894 * *$ & $.321^{* *}$ & $-.290 * *$ & 1 \\
\hline
\end{tabular}

** Correlation is significant at the 0.01 level (2-tailed).

Note. $\mathrm{CSV}$ - comfort sensation votes, $\mathrm{T}_{\mathrm{a}}$ - air temperature, $\mathrm{T}_{\mathrm{mrt}}-$ mean temperature radiant, $\mathrm{V}-$ air velocity, $\mathrm{RH}$ - relative humidity.

In Fig.4, for every $0.5^{\circ} \mathrm{C}$ of PET interval, the mean CSV was calculated in both summer and winter as suggested by Ref. (Lin, 2008). The PET ranges were -31.7 to $3.1^{\circ} \mathrm{C}$ (cold season) and 21 to $40.9^{\circ} \mathrm{C}$ (hot season). Linear regression was conducted as follows:

Cold season:

$$
\mathrm{y}=0.0497 \mathrm{x}-1.1394\left(\mathrm{R}^{2}=0.86436\right)
$$

Hot season:

$$
\mathrm{y}=-0.1043+3.1178\left(\mathrm{R}^{2}=0.71803\right)
$$

The correlation between mean CSV and PET in both summer and winter were higher than $0.7\left(\mathrm{R}^{2}=0.86\right.$ in winter, $\mathrm{R}^{2}=0.72$ in summer). The regression coefficients were 0.0497 in winter and -0.1043 in summer. The results indicate that comparing with the cold season, the residents in Shenyang were more sensitive to hot season. With the scale for subjective responses about comfort sensation in Table 2, the unacceptable PET range is lower than $-17.32^{\circ} \mathrm{C}$ in winter. The neutral PET is $29.89^{\circ} \mathrm{C}$ in summer. 


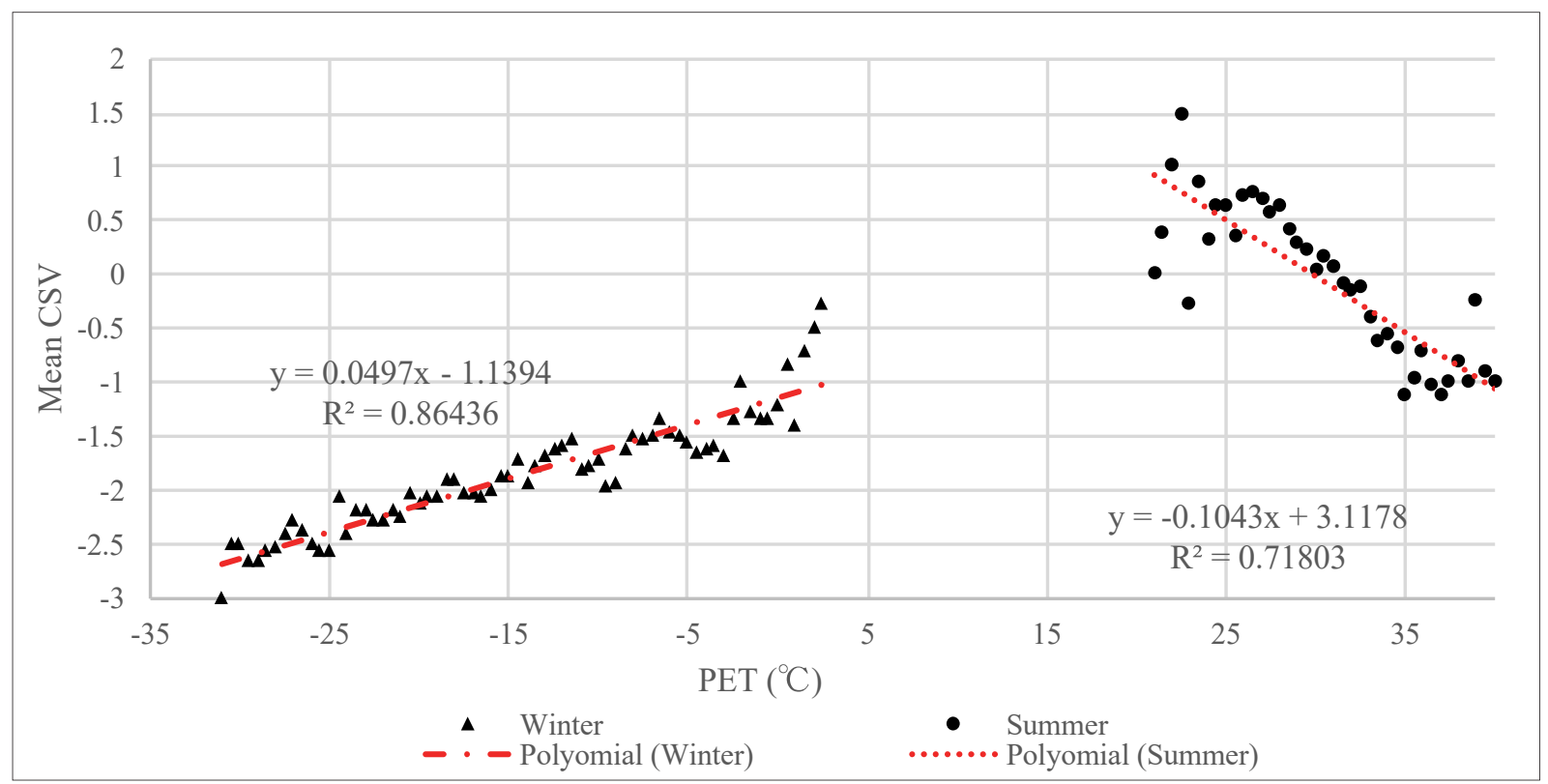

Figure 4. Relationship between mean CSV and PET

Studies had been conducted that residents in different areas shows environmental adaptability and individual differences (Nikolopoulou, 2001; Oliveira, 2007). In this research, the comfort sensation of residents in Shenyang was collected with corresponding microclimate data. Considering about the regional and individual differences, more than 2400 groups of data were employed for the sensation tendency research.

By analyzing the relation between mean CSV and each microclimate factor in summer, the variation tendencies were found: as Fig. 5 shows, CSV decreased with increasing ambient temperature, decreasing air velocity, and rose in relative humidity. Among these meteorological parameters, $29.6^{\circ} \mathrm{C}$ of $\mathrm{T}_{\mathrm{a}}, 1.1 \mathrm{~m} / \mathrm{s}$ of air velocity, and $67 \%$ of RH were threshold values for whether the environment was comfortable or not. When the $\mathrm{T}_{\mathrm{a}}$ is higher than $31.9^{\circ} \mathrm{C}$ and the RH is lower than $52 \%$, it can be seen to be uncomfortable situation. To sum up, in summer, lower ambient temperature, higher air velocity and relative humidity are more comfortable.

In winter, all the CSV was below $0^{\circ} \mathrm{C}$, that is, all the measured microclimate cannot satisfy people's comfort level. CSV decreased with increasing air velocity and decreasing ambient temperature and wind chill (Fig. 6). Among them, $-14.4^{\circ} \mathrm{C}$ of $\mathrm{T}_{\mathrm{a}},-16.5^{\circ} \mathrm{C}$ of $\mathrm{WC}$, and $1.6 \mathrm{~m} / \mathrm{s}$ of air velocity were environmental threshold values that can be accepted or not. Consequently, in winter, lower air velocity, higher ambient temperature and wind chill will make the outdoor environment more comfortable.
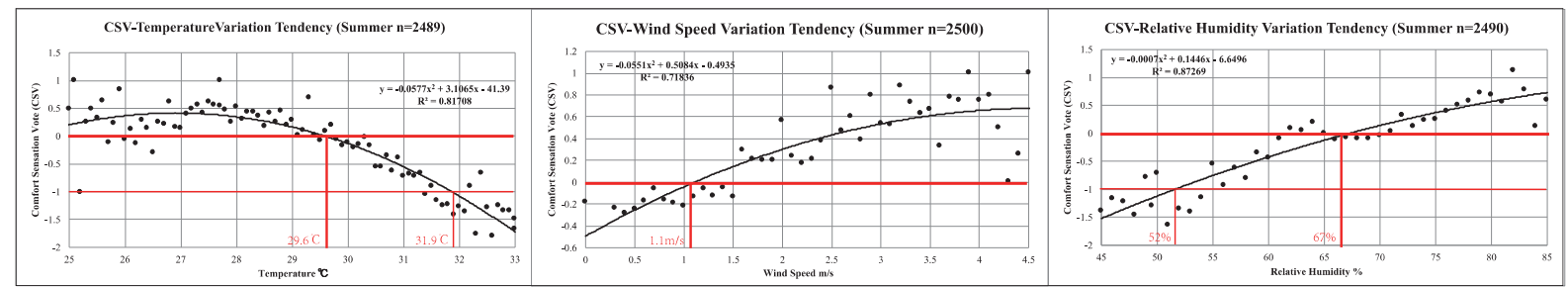

Figure 5. CSV- ambient temperature, air velocity, and relative humidity variation tendency (Summer)
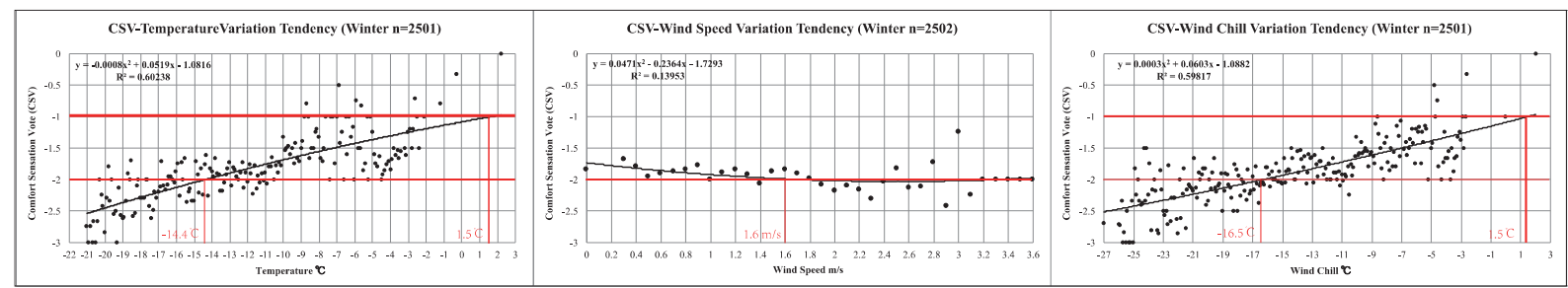

Figure 6. CSV- ambient temperature, air velocity, and wind chill variation tendency (Winter) 


\subsection{Relationships between Comfort Sensations Votes (CSV), Microclimate, and Time}

Previous studies had demonstrated that shade affect the solar radiation, thus affect the thermal sensation greatly (Lin, 2010; Hwang, 2011). Among the microclimate parameters, shade situation is easy to be distinguished and calculated. Therefore, separating the shade situation to analyze the relationship among mean CSV, microclimate factors and time may provide some distinct insights on the outdoor environment research.

Fig. 7 shows the relations among microclimate factors and CSV as a function of time in different shade situations, the following results were obtained:

In summer, CSV curves in and out of shade are obviously separate. In the morning (before 11:00 a.m.) and evening (after 17:00 p.m.), the CSV was higher than other periods, most people feel comfortable. $\mathrm{T}_{\mathrm{a}}$ and $\mathrm{RH}$ change with time gradually. From morning, Ta increase gradually until 14:30 p.m. After 14:30 p.m., the Ta started to decrease gradually. The RH was opposite to the Ta with higher rate of change. Air velocity was not about time but significantly affects instantaneous CSV.

In winter, all the measured CSV was below 0 Celsius temperature. From morning, CSV curving in and out of shade separated gradually. From 13:00 p.m. to 15:00 p.m., higher CSV can be measured especially out of the shade. Ta and RH changed gradually with time, however, wind chill changed with air velocity, significantly affected instantaneous CSV.

Consequently, the RH and $\mathrm{T}_{\mathrm{a}}$ will change with time. It can be suggesting that according to the solar radiation and spatial characteristics, some of the microclimate factors will change gradually with time. Meanwhile, the air velocity which is not related to time will also affect the CSV significantly. By according to the ruler guide in Fig.7, almost all the instantaneous change was due with the air-flow.

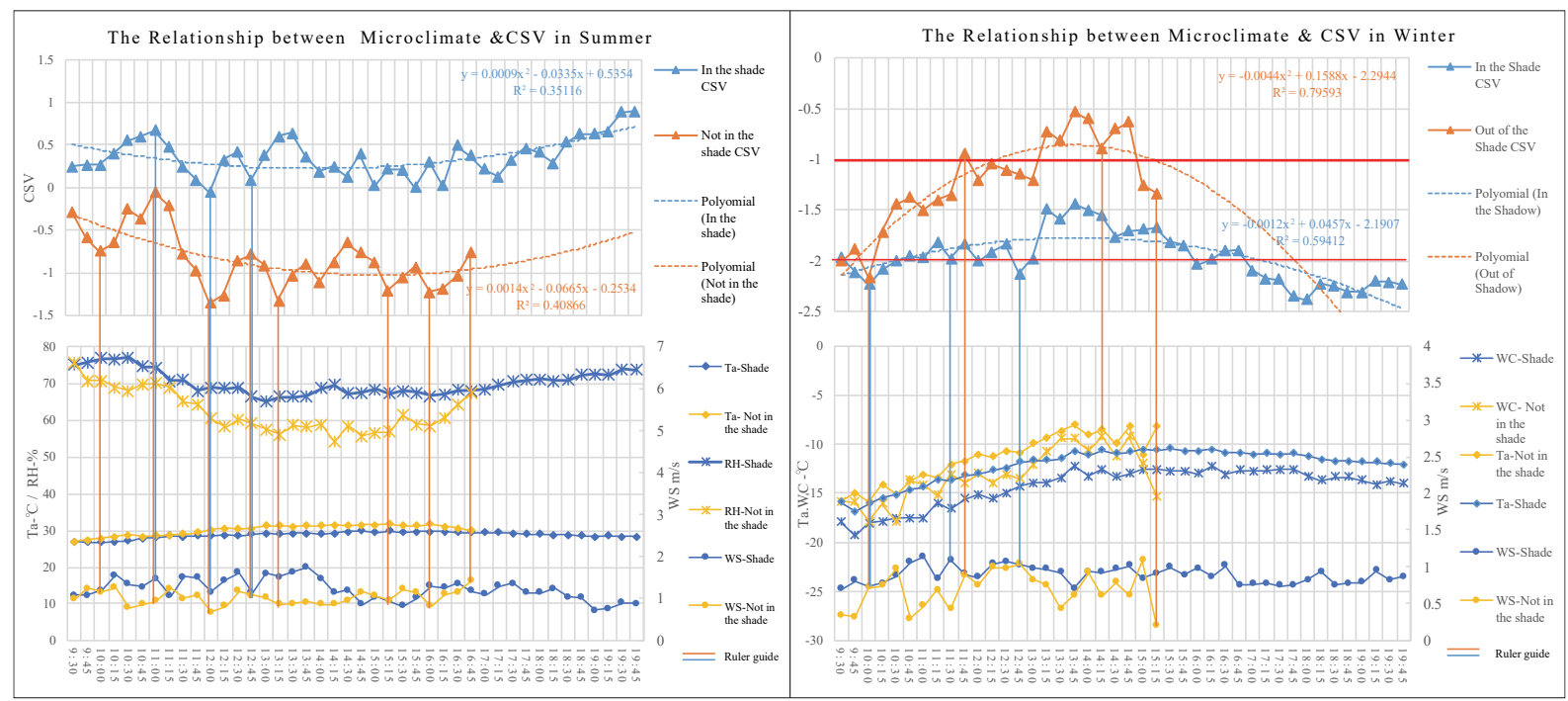

Figure 7. Relationships among mean CSV, microclimate factors with time in different shade situations

The analysis of people present is an effective way to evaluate the period people chose to stay outside. By Two days (Aug. 4, 2015 in summer and Jan. 22, 2016 in winter) were chosen to compare the differences between summer and winter by the following reasons: First, two days were all clear days. There were no influences by cloud. Secondly, these two days were all workdays and there were no commercial events during the survey periods. The pedestrian volume can be seen as normal levels. As Fig. 8 shows, both in summer and winter, total numbers relate to the time of day. The average total number of people in summer (212.10) was twice than that in winter (99.76). The least number of people were recorded during the morning (9:30-10:30) in both summer and winter. Since all the shopping malls open at 10:00, it can be speculated that the number of people affected by the function of open space.

In summer, the total number was least at 14:30, but after sunset (no direct sunlight in the study area) at about 16:30, numbers of people increased substantially. In the outdoor space, approximately $30 \%$ of people were stationary. Before sunset, the number of stationary people remained stable, and approximately $60 \%$ of them stayed in the shade. Hence, afternoon before sunset was the most unpopular time in summer, but after sunset, more people came outside. 
In winter, the biggest number of people were recorded around 3 o'clock p.m. People not in the shade related significantly to time change, and there were almost no stationary people outside. In summary, from lunchtime (12:00-13:00) to sunset at about 16:30 was the most attractive period for people in winter.

Consequently, there is a clear difference in the suitable time distribution for outdoor activities in summer and winter, that is to say, the same outdoor space should be treated differently under different outdoor environment conditions.

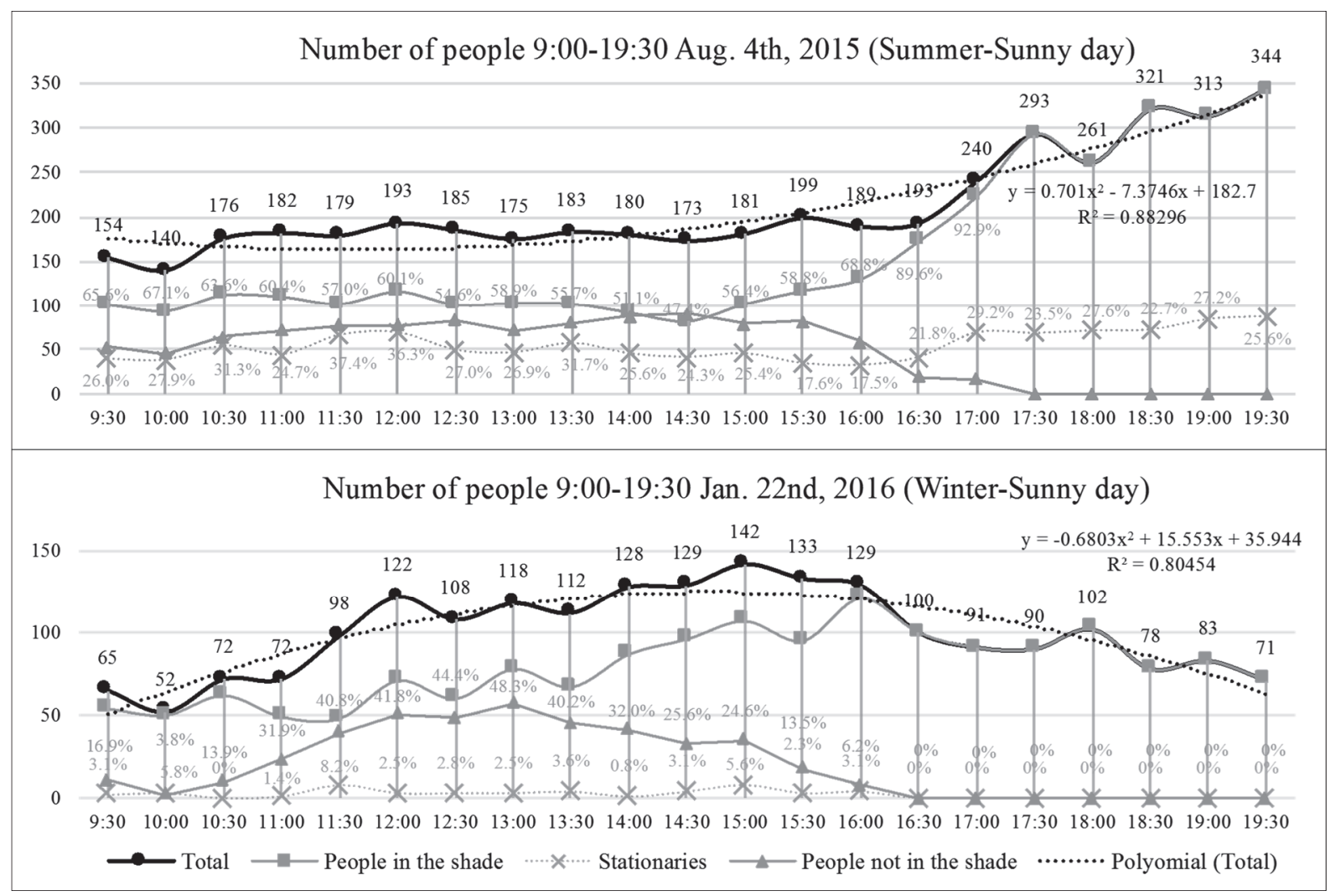

Figure 8. Number of people present in sunny day at research site (Aug. 4, 2015 and Jan. 22, 2016)

\subsection{Microclimate Analysis at Each Measurement Point}

Microclimate comparison among different areas and points were conducted. Based on different spatial characteristics, the results of microclimate are as the Fig.9. In summer and winter, the ambient temperature and humidity did not show large differences among each point. However, the relative humidity at north side where can get more sunlight was lower than other areas. Direct sunlight has the function of reducing humidity. Air-flow at center line was affected by the spatial forms more than edge sides. The highest mean air velocity in both summer and winter were found at the point No.14, where located at the narrowest place in canyon. The lowest mean air velocity was in No.5 located at building corner which can be realized as shelter from the wind.

Furthermore, the mean CSV show regularity as different microclimate. In summer and winter, the mean CSV distributions are just opposite to each other. In summer, the highest mean CSV was found at the east center line where located at the long shade and relatively narrow space with high air-flow. The lowest mean CSV was located at west center line named as unshaded and wide area where suffered relatively low air velocity. In winter, the north edge space with relatively lower air velocity and short shade got the highest mean CSV. The east center line with higher air velocity and longer shade got the lowest mean CSV. Consequently, different spatial forms will cause different microclimate conditions, thus affect the comfort level. The air velocity and shade situation are the two factors that easy to be affected by spatial form. 


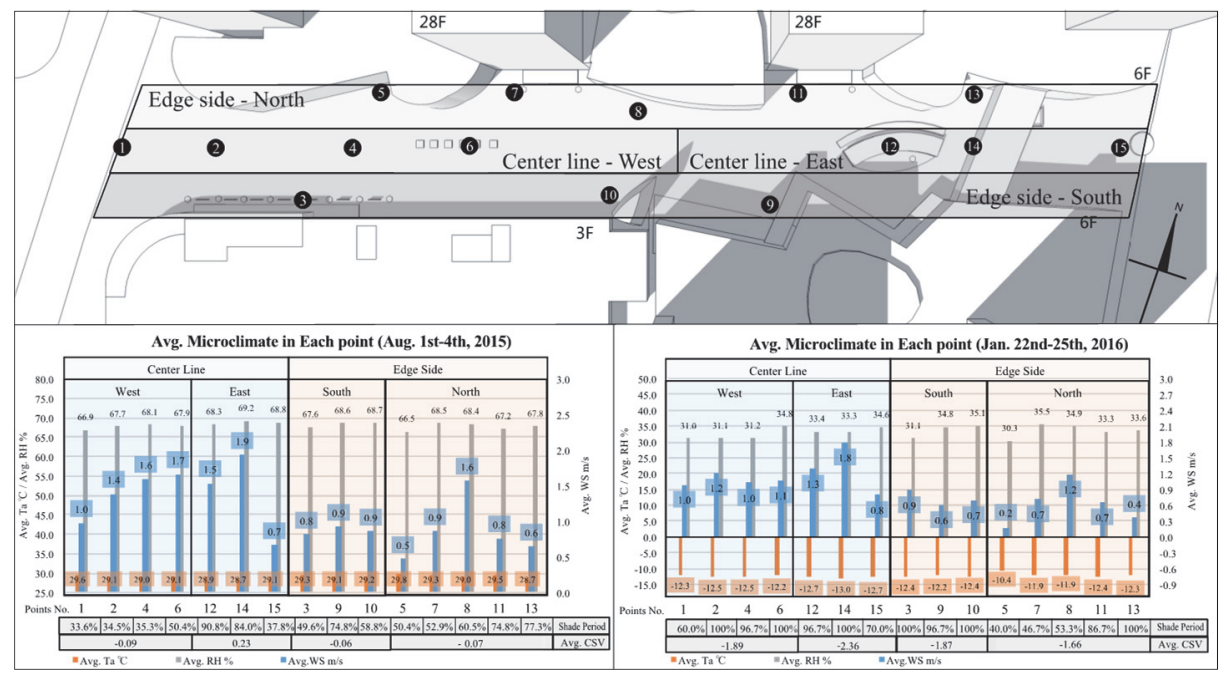

Figure 9. Mean microclimate data at each point with mean CSV for Shenyang, northern China

Two special points (Nos.5 and 14) with extreme microclimate were chosen to evaluate the microclimate factors difference during a continuous period (Aug. 1st-4th, 2015 in summer, Jan. 22nd-25th, 2016 in winter). These two points also had relatively exceptional Ta and RH. In Fig. 10, there are huge difference in air velocity and temperature between No.5 and No.14. Air velocity at No. 14 which is located at canyon "entrances" was higher than at Nos. 5 located at building corner. According to the previous study by H. Wu (1994), the skyway above the point No.14 can be seen as a diverter of air-flow. The wind pass through the skyway was separated into two parts. The area of air duct was decreased by the skyway. The air volume per unit area was increased. That caused the air velocity under the skyway to increase. The building corner at No.5 can resist the air-flow from the vertical direction. At the same time, it can also lead the air-flow from parallel direction to skim over the corner.

Differences in $T_{a}$ between the highest point (No. 5) and lowest point (No. 14) vary with shade situations. The difference in temperature between these two points can reach $6.4^{\circ} \mathrm{C}$ in summer and $9.5^{\circ} \mathrm{C}$ in winter. In terms of their spatial characteristics, No. 5 is located at the north edge of the building and is exposed to sunlight and solar reflection from the glass building. On the contrary, No. 14 is under the skyway with almost no sunlight all day long; it is also far from the building's reflection. Therefore, people can feel higher CSV at No. 14 in summer, with lower ambient temperature, and lower CSV at No. 5 in winter.

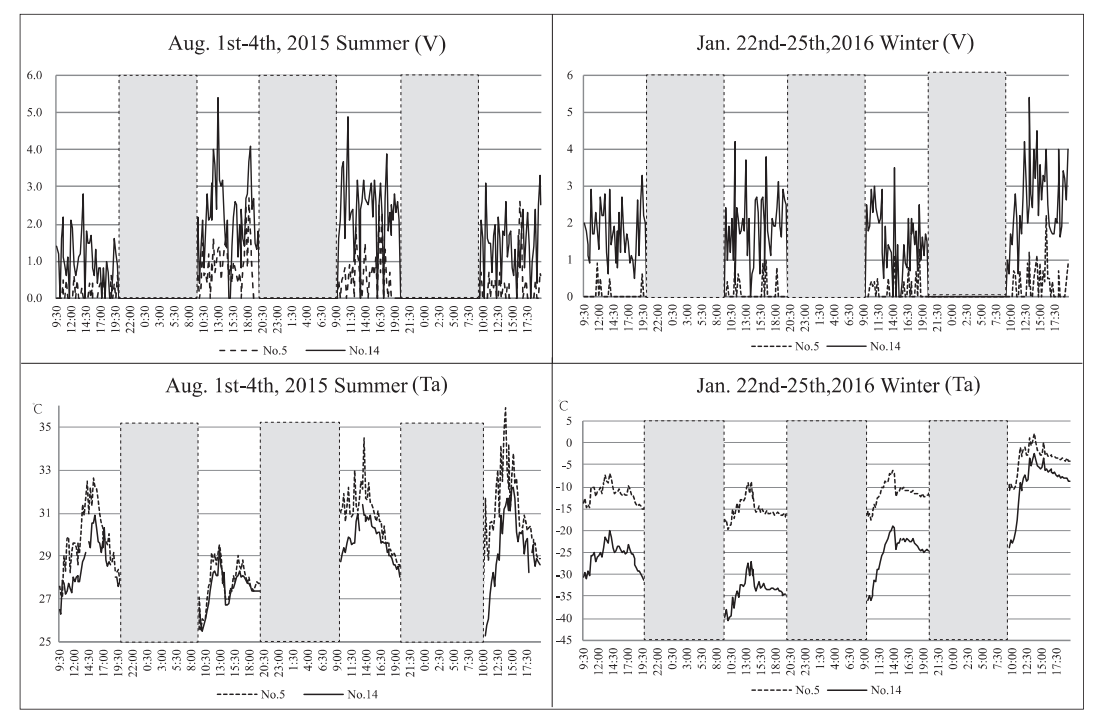

Figure 10. Air velocity and ambient temperature distributions at measurement points Nos. 5 and 14 in summer and winter 
Consequently, because of the different spatial forms, there are huge differences on microclimate in the same place to affect comfort sensation.

Outdoor distributions of people influenced by shade and spatial forms was conducted in two clear days (Aug. 4, 2015 and Jan. 22, 2016) between summer and winter. On the basis of solar simulation and high-resolution photographs, the position of people was recorded every 30 minutes. Figs. 11 and 12 shows the analyses of position relationships with shade simulation results.

In summer, according to the results 3.3, the south side suffer higher CSV than north. The area in west centre line is not popular by pedestrians. Instead, as Fig.11 shows, the east side with long periods of shade, abundant seats and other facilities can gather more people than the west side. There are sufficient seats inside the shade at the Nos. 3, 9, 11 and 12, and there are also seats under vegetation which can provide shade at No. 6. Most of the stationaries will choose these places to stay. From the above, the necessary factors for the people who stay outside in summer are shade and rest facilities.

In winter, as shown in Fig.12, people distribute evenly. Shade and rest facilities do not affect the position distribution seriously. Meanwhile, a few of people who stay outside will choose sunlight place or the place related to their destinations, for example: the entrance of the supermarket or the shopping mall or the subway station. The rest facilities and shade are not the necessary factors of attracting people to stay or sit outside in winter.

Consequently, in summer, shade influences the overall distributions of people obviously. Rest facilities with sufficient shade also attract people. In winter, no strong relations were found between shade situation and distributions of people.

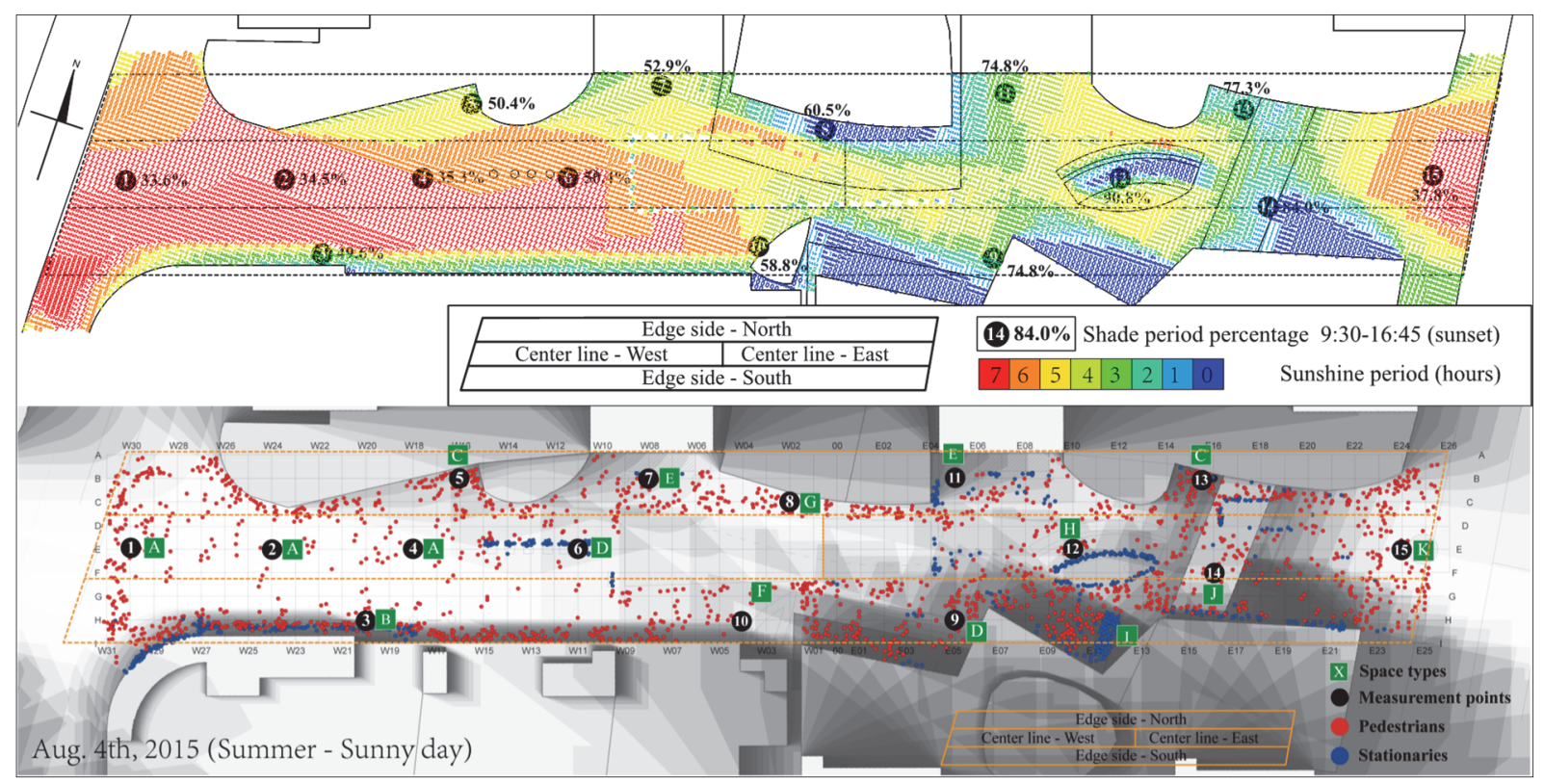

Figure 11. The position relationship with shade situation in summer 


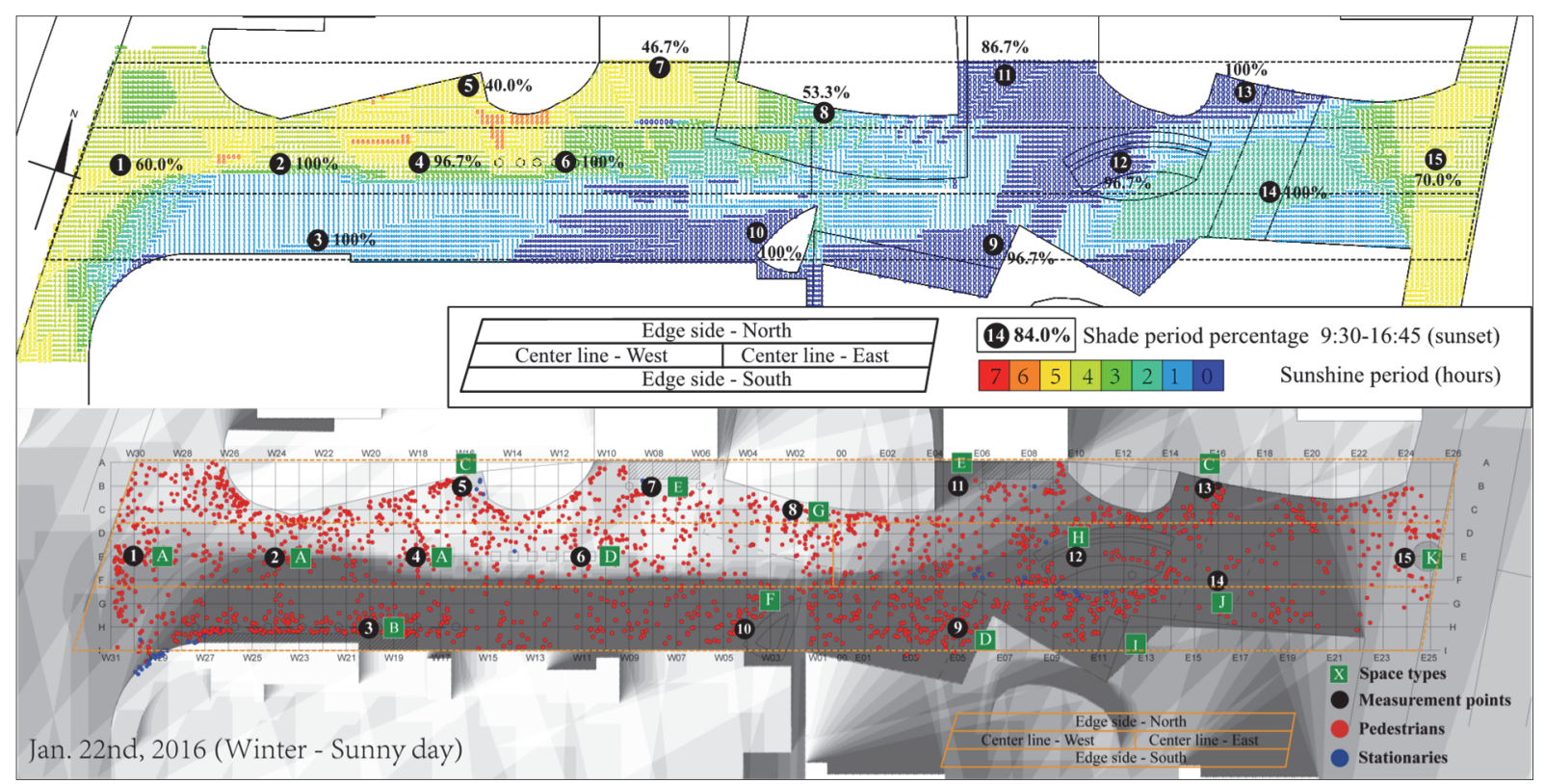

Figure 12. The position relationship with shade situation in winter

\section{Conclusions}

By using microclimate and human comfort as standards for environmental evaluation, this research conducted a field survey at a downtown pedestrian street both in hot summer and cold winter which have not been studied in the past. By analyzing how extreme weather situations influenced human behaviour and comfort, the study aimed to discover the microclimate associated with open space use, to support further open space design. The survey has demonstrated the following:

- Microclimate obviously affected people's comfort. In addition, the influence effect in summer and winter were distinct. No single parameter will affect the spatial comfort as a leading role. All the factors have come together on the comfort sensation.

- In summer, lower $\mathrm{T}_{\mathrm{a}}$, higher air velocity, RH and more shade brought higher CSV. $29.6^{\circ} \mathrm{C}$ of $\mathrm{T}_{\mathrm{a}}, 1.1 \mathrm{~m} / \mathrm{s}$ of air velocity, and $67 \%$ of RH were threshold values for whether the environment was comfortable or not. In winter, higher $\mathrm{T}_{\mathrm{a}}$, lower air velocity and less shade, caused higher CSV. $-14.4^{\circ} \mathrm{C}$ of $\mathrm{T}_{\mathrm{a}},-16.5^{\circ} \mathrm{C}$ of WC, and $1.6 \mathrm{~m} / \mathrm{s}$ of air velocity were environmental threshold values that can be accepted or not.

- The residents in Shenyang were more sensitive to hot season than cold season.

- Among all meteorological factors, change of $\mathrm{T}_{\mathrm{a}}, \mathrm{RH}$, and shade situation were closely related to time and changed evenly. However, air velocity changed unevenly and significantly affected instantaneous comfort.

- Spatial form affected the shade situation and air velocity, and further affected comfort sensation.

- The human present is related to microclimate that change along with time, that is, in summer, afternoon before sunset (at about 16:30) was the most unpopular time, but after sunset, more people came outside. From lunchtime (12:00-13:00) to sunset at about 16:30 was the most attractive period for people in winter.

- Different spatial forms cause the differences of microclimate, thus affect comfort sensation. In summer, shade influences the overall distributions of people obviously. Rest facilities with sufficient shade also attract people. In winter, no strong relations were found between shade situation and distributions of people.

In such kind of city central open space suffering hot summer and cold winter, grasping the rules of the microclimate which affect the people's sensation and spatial behaviors can help the designers and planners to create more comfortable open space. By optimizing the spatial form, it is possible to change the wind environment and shade situation better. Meanwhile, understanding the time-microclimate rules, arranging the open space facilities in suitable time and season are important to raise the space utilization. From the conclusions above, densely populated open space design guidelines based on extreme microclimate and spatial behaviour are proposed:

- In hot season, attractive open space design should focus on rest facilities with shade and ventilation. In the 
daytime, setting the broad-leaved vegetation and roofs on the widely open space can raise the comfort level. Adding rest facilities at the well-ventilated areas also can raise the environment comfort. Meanwhile, nightscape design should be especially considered.

- In cold season, the rest area should be arranged to combine well with relative behaviours around the buildings. Meanwhile, shelter from wind is a key point for a better winter environment. The design of the daytime environment, especially from noon to sunset, should be properly addressed.

\section{Acknowledgments}

This work was supported by JSPS KAKENHI Grant Number JP25249082. The first author is supported by the Chinese Scholarship Council (CSC) scholarship (File No. 201406080003). The authors would like to express their appreciation to students from JangHo Architecture Collage in North-eastern University, China, who helped the authors to finish the Shenyang survey. They are Rundong LI, Guangyu MA, Weisi HUANG, Jiaxin LV, Fan XU, Peiyang SUN, Chang LIU, Hengyi CAI, Chuyao DONG, Shafei JI, Jiahui Yang, Yifeng WANG and Duerjia GUAN.

\section{References}

Andreou, E. (2013). Thermal comfort in outdoor spaces and urban canyon microclimate. Renewable Energy, 55, 182-188. https://doi.org/10.1016/j.renene.2012.12.040

Andreou, E. (2014). The effect of urban layout, street geometry and orientation on shading conditions in urban canyons in the Mediterranean. Renewable Energy, 63, 587-596. https://doi.org/10.1016/j.renene.2013.09.051

Andreou, E., \& Axarli, K. (2012). Investigation of urban canyon microclimate in traditional and contemporary environment. Experimental investigation and parametric analysis. Renewable Energy, 43, 354-363. https://doi.org/10.1016/j.renene.2011.11.038

Blalock, H. M. (1972). Social statistics. New York: McGraw-Hill.

Bourbia, F., \& Boucheriba, F. (2010). Impact of street design on urban microclimate for semi-arid climate (Constantine). Renewable Energy, 35(2), 343-347. https://doi.org/10.1016/j.renene.2009.07.017

Carr, S., Francis, M., Rivlin, L. G., \& Stone, A. M. (1993). Public space. Cambridge, New York: Cambridge University Press.

China Meteorological Administration, National Meteorological Information Center, Website of Chinese Meteorological Data. (1971-2014). The database of climate standard daily value in Chinese international ground switching center (cited 2009-2014 Jul., Aug., Dec., Jan., Feb.) [database on the Internet]. Retrieved from http://data.cma.cn/data/detail/dataCode/A.0029.0001.html

China Meteorological Bureau, Climate Information Center, Climate Data Office and Tsinghua University, Department of Building Technology. (2005). China Standard Weather Data for Analyzing Building Thermal Conditions. Beijing: China Building Publishing House.

Chinese State Bureau of Technology Supervision (CSBTS) \& Chinese Ministry of Construction. (1994). GB50178 Standard of Climate Regionalization for Architecture. Beijing: Standard Press of China.

Eliasson, I., Knez, I., Westerberg, U., Thorsson, S., \& Lindberg, F. (2007). Climate and behavior in a Nordic city. Landscape and Urban Planning, 82, 72-84. http://dx.doi.org/10.1016/j.landurbplan.2007.01.020

Erell, E., Pearlmutter, D., \& Williamson, T. (2012). Urban microclimate: designing the spaces between buildings. New York: Routledge.

Gehl, J. (2011). Life between buildings: using public space. Washington, DC: Island Press.

Givoni, B. (1998). Climate considerations in building and urban design. New York: John Wiley \& Sons.

Handbook, A. S. H. R. A. E. (2001). Fundamentals. American Society of Heating, Refrigerating and Air Conditioning Engineers, Atlanta, 111.

Hoppe, P. (1999). The physiological equivalent temperature - a universal index for the biometeorological assessment of the thermal environment. International Journal of Biometeorology, 43(2), 71-75. https://doi.org/10.1007/s004840050118

Hwang, R. L., Lin, T. P., \& Matzarakis, A. (2011). Seasonal effects of urban street shading on long-term outdoor thermal comfort. Building and Environment, 46(4), 863-870. https://doi.org/10.1016/j.buildenv.2010.10.017 
Lai, D., Guo, D., Hou, Y., Lin, C., \& Chen, Q. (2014). Studies of outdoor thermal comfort in northern China. Building and Environment, 77, 110-118. https://doi.org/10.1016/j.buildenv.2014.03.026

Li, S. (1994). User's behaviour of small urban spaces in winter and marginal seasons. Architecture and Behaviour, 10, 95-109.

Lin, T. P., \& Matzarakis, A. (2008). Tourism climate and thermal comfort in Sun Moon Lake, Taiwan. International Journal of Biometeorology, 52(4), 281-290. https://doi.org/10.1007/s00484-007-0122-7

Lin, T. P., Matzarakis, A., \& Hwang, R. L. (2010). Shading effect on long-term outdoor thermal comfort. Building and Environment, 45(1), 213-221. https://doi.org/10.1016/j.buildenv.2009.06.002

Marcus, C. C., \& Francis, C. (Eds.). (1997). People places: Design guidelines for urban open space. New York: John Wiley \& Sons.

Maruani, T., \& Amit-Cohen, I. (2007). Open space planning models: A review of approaches and methods. Landscape and urban planning, 81(1), 1-13. http://dx.doi.org/10.1016/j.landurbplan.2007.01.003

Matzarakis, A., Rutz, F., \& Mayer, H. (2007). Modelling radiation fluxes in simple and complex environments - application of the RayMan model. International journal of biometeorology, 51(4), 323-334. https://doi.org/10.1007/s00484-006-0061-8

Mayer, H., \& Hoppe, P. (1987). Thermal comfort of man in different urban environments. Theoretical and applied climatology, 38(1), 43-49. https://doi.org/10.1007/BF00866252

Meng, X. W., \& Setoguchi, T. (2010). Development of Urban Design Guidelines with Wind Tunnel Simulations for Downtown Districts in Winter Cities. Journal of Asian Architecture and Building Engineering, 9(2), 355-362. https://doi.org/10.3130/jaabe.9.355

Ministry of Housing and Urban-Rural Development of the PRC(MOHURD). (1994) Chinese standard for assessment parameters of sunlight on building GB/T50947- 2014. Beijing: Standard Press of China.

Nikolopoulou, M., \& Lykoudis, S. (2007). Use of outdoor spaces and microclimate in a Mediterranean urban area. Building and Environment, 42(10), 3691-3707. http://dx.doi.org/10.1016/j.buildenv.2006.09.008

Nikolopoulou, M., Baker, N., \& Steemers, K. (2001). Thermal comfort in outdoor urban spaces: understanding the human parameter. Solar energy, 70(3), 227-235. https://doi.org/10.1016/S0038-092X(00)00093-1

Nunez, M., \& Oke, T. R. (1977) The energy balance of an urban canyon. Journal of Applied Meteorology, 16, 11-19. https://doi.org/10.1175/1520-0450(1977)016<0011:TEBOAU $>2.0 . C O ; 2$

Oliveira, S., \& Andrade, H. (2007). An initial assessment of the bioclimatic comfort in an outdoor public space in Lisbon. International Journal of Biometeorology, 52(1), 69-84. https://doi.org/10.1007/s00484-007-0100-0

Setoguchi, T. (2004). Efficiencies of infill developments against snow problem in winter cities-the snow simulations for desirable block designs using wind tunnel. Journal of Asian Architecture and Building Engineering, 3(2), 335-340. https://doi.org/10.3130/jaabe.3.335

Setoguchi, T. (2008). New urban design approaches with snow simulations for cold and snowy cities. Journal of Asian Architecture and Building Engineering, 7(1), 93-99. https://doi.org/10.3130/jaabe.7.93

Setoguchi, T. (2009) The development of urban design planning process linking with snow and wind environmental assessments on the urban complex redevelopment project in snowy and cold cities, J. Archit. plan., AIJ, 74(642), 1777-1786.

Setoguchi, T., \& Tsutsumi, T. (2007). Snow and wind environmental assessment on the public space comparing high-rise and medium-rise building blocks using the wind tunnel simulation. Journal of Architecture and Planning (Transactions of AIJ), (614), 167-174.

Shahrestani, M., Yao, R., Luo, Z., Turkbeyler, E., \& Davies, H. (2015). A field study of urban microclimates in London. Renewable Energy, 73, 3-9. https://doi.org/10.1016/j.renene.2014.05.061

Shimazaki, Y., Yoshida, A., Suzuki, R., Kawabata, T., Imai, D., \& Kinoshita, S. (2011). Application of human thermal load into unsteady condition for improvement of outdoor thermal comfort. Building and Environment, 46(8), 1716-1724. http://dx.doi.org/10.1016/j.buildenv.2011.02.013

Spagnolo, J., \& De Dear, R. (2003). A field study of thermal comfort in outdoor and semi-outdoor environments in subtropical Sydney Australia. Building and environment, 38(5), 721-738. http://dx.doi.org/10.1016/S0360-1323(02)00209-3 
Tanabe, S. I. (1988). Thermal Comfort Requirements in Japan (Doctoral dissertation) Waseda University, Tokyo, Japan.

The National Weather Service (NWS). (2011). The NWS Wind Chill Temperature (WCT) index [database on the Internet]. MD (US). Retrieved from http://www.nws.noaa.gov/om/cold/wind-chill.shtml

Thorsson, S., Honjo, T., Lindberg, F., Eliasson, I., \& Lim, E.-M. (2007). Thermal comfort and outdoor activity in Japanese urban public places. Environment and Behavior, 39, 660_684. http://dx.doi.org/10.1177/0013916506294937

Thorsson, S., Lindberg, F., Eliasson, I., \& Holmer, B. (2007). Different methods for estimating the mean radiant temperature in an outdoor urban setting. International journal of climatology, 27(14), 1983-1993. http://dx.doi.org/10.1002/joc.1537

VDI. (1998). Methods for human biometeorological evaluation of climate and air quality for the urban and regional planning. Part I: Climate. VDI guideline 3787, Part 2, Beuth, Berlin, Germany.

Watanabe, N., Setoguchi, T., Sato, K., \& Tsutsumi, T. (2016). New city block design approaches incorporating environmental assessment for downtown districts in cities with severe winter climates. Journal of Asian Architecture and Building Engineering, 15(3), 455-462. https://doi.org/10.3130/jaabe.15.455

$\mathrm{Wu}$, H. (1994). Pedestrian-level wind environment around buildings (Doctoral dissertation). Concordia University, Montreal, Quebec, Canada

Zhang, H. Ch., \& Peng, X. L. (2008). Mold Vigor Block: Shenyang Zhongjie Commercial Pedestrian Street User-friendly Research Analysis. Modern Urban Research, 23(12), 29-37.

\section{Copyrights}

Copyright for this article is retained by the author(s), with first publication rights granted to the journal.

This is an open-access article distributed under the terms and conditions of the Creative Commons Attribution license (http://creativecommons.org/licenses/by/4.0/). 